\title{
Religious Travellers' Improved Attitude towards Nature
}

\author{
Rafael Robina Ramírez ${ }^{1, *}$ (1) and Manuel Pulido Fernández 2 (1) \\ 1 Business and Sociology Department, University of Extremadura, Avenida de la Universidad s/n, \\ 10071 Cáceres, Extremadura, Spain \\ 2 Geography Department, University of Extremadura, Avenida de la Universidad s/n, 10071 Cáceres, \\ Extremadura, Spain; mapulidof@unex.es \\ * Correspondence: rrobina@unex.es; Tel.: +34-927-257-480
}

Received: 26 June 2018; Accepted: 22 August 2018; Published: 28 August 2018

\begin{abstract}
Pilgrimage is one of the most ancient forms of tourism. Nowadays, it is becoming a mass phenomenon that can lead to serious problems of environmental degradation in valuable sites. In this work, we have analysed by means of a structural equation model how religious consciousness is inspired in the religiosity/spirituality of each pilgrim. It could predict its effects on tourists regarding an improved (i.e., sensitised and more sustainable) attitude towards nature. The study was carried out in Guadalupe, Spain, which is a commonly known pilgrimage destination since 1389. A total of 203 visitors were surveyed using a questionnaire composed of 16 questions, divided into 4 dimensions (enriched attitudes toward nature, religious consciousness, sustainable development, and environmental human development), which were used as constructs in the model. The results showed how religious consciousness positively influences sustainable development $(\beta=0.657$, $t=11.306)$ and environmental human development $(\beta=0.566, t=8.255)$ explaining $75.6 \%$ of religious travellers' more sensitive attitudes towards nature. Our findings suggest that a deeper research, on the role played by religiosity as a seed of fostering sustainability, is still needed.
\end{abstract}

Keywords: religious travellers; pilgrimage; nature; sustainable development; religious consciousness; human development

\section{Introduction}

In the western monotheistic traditions, nature has played a second role. The natural world has often primarily been seen as a set of resources for human utility. Simultaneously, these religious traditions contain scriptural passages and sustained practices in which we would now read a respectful view of the environment.

For instance, Judaism extended its notion of a covenant between the Creator and human beings to all creation. Christianity, in principle, sees the natural world as sacred, among Muslims there is the precept that the natural world belongs to God, not to humans [1].

In the last decades, a vigorous debate has been undertaken between anthropocentrism, based on man's benefit, and environmental stewardship [2], between those who emphasise the role of nature created explicitly for man's benefit, which has deteriorated the environment [3], and others who enhance the role of stewardship [4]. In these debates, two opposed positions emerge: one that denies that it would be possible that the Christian faith would contribute to nature's protection, and one that finds in the Christian faith clear indications that it could take up inspired environmental responsibility [5].

At the side of those in favour of Christianity-inspired stewardship, various authors have pointed out that some theologians have begun to find ways to connect the new call for ecological responsibility with passages from the Christian Scriptures [6] stressing religiosity as a way to inspire environmental 
activism [7] by expressing admiration towards nature [8]. Smart [9] gives a wide definition of how spirituality is, particularly related to faith commitment and its expression [10], accepting as an expression of faith commitment after the pilgrimage. Northcott [11] provides an excellent essay on different views about the existing link between the Bible (and Qur'an) and Ecology. In this line, Delio [12] advocates the inseparability of the environmental and scriptural perspective of nature.

At the side of those who deny the connection between religiosity and environmental activism, it has been emphasised that the human desire to control nature has resulted in unprecedented environmental destruction [13]. Interestingly, as Gardner [1] has pointed out, since natural devastation has gradually gained relevance, the religious and environmental communities have expressly engaged each other on the agenda of religious and environmental leaders.

Then, leaders from different religions have taken seriously those who threaten nature. In fact, since the mid-1980s, Hindu leaders have been very active in protecting nature by releasing environmental statements. Ecumenical Patriarch Bartholomew as well as Pope John Paul II have openly pushed to analyse the human consequences on nature. Through these voices, religious leaders and believers have perceived the environment as something worthy of protection and preservation [5] but the opposition between anthropocentric and ecological views of nature still remains. To overcome that traditional difference, religious leaders have stressed the principle of stewardship over the human dominion of nature, which, in turn, encourages individuals to be environmentally responsible [14]. Have those environmental meetings and responsible statements over nature had any effect on the devoted faithful?

In the last decades, countless pilgrims daily make their way to the innumerable sanctuaries and shrines dedicated to Saint Mary to discover God's ways or to undertake them anew, and to find peace of soul and consolation in affliction. Likewise, thousands of pilgrims come to sacred places to pray or express their faith and devotion. Religion and nature converge in faithful travellers in their pilgrimage towards sacred places [15]. When they set off on a journey, nature and religion are intertwined everywhere, across rivers, mountains, hills, pastures, etc. In other words, travellers might find the connection between nature and divinity on their travels [16]. Recently, an increasing number of people have found these religious paths to be the perfect setting for intimate experiences [17].

One of the sacred places that have contributed to keeping the faith alive has been the Royal Monastery of Santa María de Guadalupe (Spain). This Catholic monastery was one of the first pilgrimage centres in Europe [18] and, since 1389, reverence for the Black Virgin has spread worldwide $[19,20]$, so much so that it was declared a World Heritage Site by United Nations Educational, Scientific and Cultural Organization UNESCO in 1993, (UNESCO World Heritage List) due to the outstanding historical value of the Monastery [21]. It is settled in the heart of an environmental setting called "Villuercas-Ibores-Jara". It was declared a UNESCO Global Geopark in 2011 for the beauty of this unique landform, characterised by structurally controlled morphological features responsible for the intensely folded and fractured landscape [22].

Travellers express their religious attitudes in relation to nature along the path towards sacred places precisely within the context of these two well-known religious and environmental sites. So, religion continues to flourish and in many circles it is being revived as a source of ecological worldviews. Many religious leaders are also becoming more environmentally aware and have started to encourage pro-environmental behaviour [1]. Those leaders have also recently recognised the need to develop their religious consciousness to emphasise their moral and ethical principles that support respect for the environment, their ecotheologies [23,24].

As some scholars have stressed, religious consciousness influences their ultimate control over their destiny [25] and the individual's action [26]. Those actions related to nature are shaped by their religious consciousness, as well as legal and political ones [27] (p. 138). In the case of pilgrims, the paper analyses if this religious consciousness has an impact on the way they relate to nature. Those environmental attitudes are closely related to environmental awareness [28]. Some authors relate those attitudes to formative experiences [29] or aging experiences [30]. The goal of raising 
environmental awareness of the public can be improved, either it is understood as an end in itself or being translated into action [31].

Sánchez García and Díez Sanz [32] added another dimension that connects religiosity and environmental awareness, namely human development, which is understood to be the human ability to be involved in protecting nature. From the environmental psychology, scholars have argued that ecological goals and human development must be addressed in parallel [33]. In this process has to be analysed not only the human values associated with the environment [29] but also the environmental values as engendering environmental attitudes and behaviour to respect nature [34,35]. As some scholars have pointed out, the relationships between human values and environmental attitudes can predict the individual's behaviour towards nature [36,37].

Then, the objective of the article is to study if "Religious Consciousness' influences 'Environmental Awareness', 'Human Development', and 'Improved Attitudes towards Nature' amongst religious travellers. As Sarstedt et al. [38] (p. 4002) has pointed out, through Structural equation modeling-Partial Least Square SEM-PLS Path Modelling, nonobserved variables related to focal concepts such as attitudes, perceptions, and behavioural intentions can be measured. PLS Path Modelling also works appropriately with complex variables among repetitive interactions and provides reliable explanatory and predictive information [39].

In this work behavioural variables have been selected. They are Improved Attitudes towards Nature (IAN), Religious Consciousness (RC), the Sustainable Development of Nature (SDN) to protect the environment and the promotion of Environmental Human Development (EHD) through environmental education and activities.

The data has been drawn from questionnaires completed by pilgrims visiting the sacred monastery in Guadalupe between the months of July and September 2017. As the vast majority of the devoted attendees profess the Christian faith, whether they are Catholic or Protestant, the study addresses the research in the Christian domain.

The contribution of this paper is, therefore, twofold: (1) decipher how religious belief affects travellers' environmental perception by exploring whether their religious consciousness towards that religious monastery positively influences the environment; and (2) ascertain whether travellers' human flourishing plays a key role in protecting nature. Very little research has studied the connection between Religious Consciousness (RC) and these constructs in too much detail. This paper also introduces two novelties in this line of thought: (1) the analysis between Religious Consciousness and the environmental preservation of that revered place; (2) the influence of Religious Consciousness on Human Capabilities and developing respectful Attitudes towards Nature.

This paper is organised into six sections. Section 1 introduces the study. Section 2 describes in the literature review what religious consciousnesses means to visitors to sacred places assessing not only the environmental challenges travellers must face but also the human capabilities to be developed by pilgrims to respect nature. Section 3 analyses the methodology. Section 4 delves into the results. Section 5 addresses the outcome of the study, and the discussion and finally, Section 6 describes the conclusion and limitations of the paper.

\section{Literature Review}

\subsection{Religious Consciousness (RC)—The Religious Approach to the Environment}

Consciousness as an attribute of rational human beings enables an understanding of the intangible living aspects of life. Consciousness is driven by moral guidance in terms of cognitive structures and intellectual acts. This guidance is what enables humans to know what is right or wrong and make the right choices in life [40]. The moral dimension of consciousness develops moral judgements about desirable attitudes and behaviours, which shape the individual's values, regardless of whether they focus on one's self or society [41]. 
Even though much has been written about the relation between attitudes and behaviours, very little has been found about the way to improve and predict behaviours [42] (p. 48) and its relation with social culture $[29,43]$. Scholars have also linked values and beliefs to structures of motives as a way to understand the relationship between both [44]. These motives to orientate attitudes and behaviours towards values can be nurtured and grown by the religiosity of the community.

Either in religious or secular context, moral consciousness brings the ability to differentiate between right and wrong behaviour. From the religious approach, that consciousness can be guided according to religious rules. In Christian denominations, those rules were originally settled within the covenant between creator and creature [45]. They set limits on how and what the most exalted creatures "humans" may do in creation [11] and what happens in nature when the limits are ignored [46].

How those rules, attitudes, and behaviours are applied to affect positive developments and onwards attitudes towards nature is complex. As Gardner [1] (p. 25) claims in the article "invoking the spirit": environmentalist and religious people have trouble understanding each other. However, even though the perspectives are often different, they have in common the environmental values [47].

The great objective is to define these values and knowledge [45]. Gardner [48] highlights ways to integrate human attitudes into sustainable behaviour based on values and beliefs. Every human can somehow internalise such behavioural rules in their lives. In other words, from this religious framework, consciousness nurtures right behaviour. It also inspires the sacred values and affective-motivational examples. The integration process between human attitudes into sustainable behaviour plays a key role to maintain a stable motivation to orientate attitudes towards values. From this theoretical scenario, behavioural skills can be acquired from meaningful and motivating religious examples comprised in sacred books.

Then, values, religion, and spirituality can become an important factor to transform the human consciousness in a sustainable future [49] (p. 4). However, the theoretical scenario that relates consciousness and right attitudes differs from empirical studies about respectful behaviour towards nature. This gap has shown the real complexity to integrate those intellectual and volatile attributes into improved environment in a practical way.

As a clear example, religious and environmental organisations in Australia have attempted the difficult process of integrating profound values into improved behaviours towards nature. Those profound values were interpreted by the United Nations, cultural and spiritual ones [50] (p. 274).

However, opposite relationships show the complexity of maneuvering attitudes and religious consciousness towards improved nature. According to Clements et al. [51], in a study among green Christians in the U.S. regarding attitudes towards nature, the results show that there is no positive influence of religious beliefs towards nature. This stream of thought has pointed out that several studies show that Christians in general have negative associations with environmental concerns [2,51-53] when compared with non-Christians $[3,54]$. Moreover, the attitudes of conservative believers are shown to have even less concern about the environment $[53,55]$ than those who have a liberal approach to the Bible [56,57].

Other studies did not provide us with any relationship between attitudes towards nature in believers. Konisky [58] justified in his research that there is no link between religious awareness and environmental consciousness. In fact, multiple measures of environmental attitudes reveal little evidence that Christian faith has influence on respecting nature [58].

Along this spectrum of studies, the challenge is not only to reduce the gap between theoretical and empirical studies by making proposals to improve attitudes toward nature, but also to work out a common language between science and religion, to channel the visible concern in building a sustainable world [13].

That common language is based on the mutual intention to share, in their search for truth and knowledge, the same ultimate objective of revealing the underlying causes in the patterns of the universe and determining our place in these patterns. Facts from science or myths from religion enrich our understanding of the world beyond everyday experiences [59]. 
This mutual understanding leads to the process of building a common language. In fact, people from diverse backgrounds believe that the environmental crisis will only be reduced if we are able to increase human respect for nature. Although this process can be random, deceptive, and harsh, spirituality gives meaning to it. It involves a process of detachment from personal benefit dealing with nature and promoting a generous perspective towards others and living creatures [60].

In this intellectual journey, religiosity can turn individuals into a better position to solve the environmental crisis [61,62]. The growing role for religions in shaping attitudes and action is gaining relevance to develop a broader commitment to environmental protection and restoration [63]. However, to achieve this goal it is important for environmentalists to see the benefits of making approaches to the spiritual side, by mobilizing the faithful for more positive environmental action. According to this line of engagement, bridges need to be built to end the historic trouble between science and spirit [62] (p. 22).

As a result, religious initiatives are created to integrate either secular organisations or religious authorities. This is how the Interfaith Partnership for the Environment was created. Scholars and religious leaders within different denominations and secular organisations started to work together. They published the book "Earth and Partnership for the Environment" United Nations Environment Programme (UNEP) [61]. Similarly, the World Bank has been working in the same direction since 1998, raising interfaith dialogues among churches within climate change programmes. Then the World Council of Churches' Climate Change Programme was formed to lobby governments and international organisations to formulate policies to combat climate change.

It was also the intention of one of the meetings held at Venice two decades ago. As a result, Pope John Paul II and the Ecumenical Patriarch signed an environmental declaration to protect nature. Many other examples have recently been promoted. In the Apostolic Letter Octogesima Adveniens, Pope Paul VI [64] revealed the devastating and destructive human approach towards nature in the last decades. Likewise, Benedict XVI [65] stressed his concern about how the models of growth have become gradually more harmful to the environment.

It was also the spirit of the meeting among different religious denominations in Assisi, Italy, held in the late 1980s. Proposals for raising environmental awareness were taken into consideration. After this, other religious initiatives and Partnerships on Environment have taken place [1]. More recently, Pope Francis wrote the inspiring Encyclical Letter "Laudato Si", to invite others to follow the St. Francis example to care for the Creation [66]. This letter connects environmental degradation, poverty, and society's moral obligation to respond to those challenges [67].

To put those desirable intentions and promising words into action, it is necessary to empower organisations-be it secular or faithful—to connect both sides through a common language as proposed:

- Introducing environmental education into religious educational programmes and vice versa. Not only can environmentalists learn from religious environmental programmes [68], but religious environmental education programmes can be drafted from secular environmental education materials [69]. Experiential environmental programmes have included religious studies and methodologies to improve the process of environmental learning [70].

- Proposing an environmental behaviour model by linking concepts and teaching modules successfully applied in environmental educational activities in Christian and Jewish denominations [71]. For instance, by connecting ethical behaviour between humans, God and Creation, seeing life and nature as a gift as it is written in Scriptures.

- Avoiding unnecessary clashes in the process of developing that common language in environmental education. The Biodiversity Project is one of the clear examples of agreement between religion and environmentalists [72].

- Relating environmental integrity, either in scriptures and the devoted faithful life, to enhance respectful attitudes towards nature [73]. In fact, environmental integrity has followed the religious teachings to learn from its respectful attitudes towards nature [74]. 
- Promoting environmental forum where religious values can be connected with respectful behaviour toward nature [75] (p. 91).

- Learning from Sacred Scriptures to promote motivation and empowerment to protect nature (e.g., Revelation 11:18). Those feelings can make a difference on attendances to respect nature.

In the process to put all those suggestions into practice, it is important to be aware that they cannot be resolved in a short period of time. Attitudes and behaviours take necessary time to change. Along this long process, religious perspective of life can help to improve attitudes towards nature.

As soon as all those proposals have been undertaken, they need to be evaluated to experience what actions are really taking place and how the process in reducing the gap between environmentalist and religious authorities in every territory can be achieved.

Regarding the religious travellers, sacred heritage destinations are developing protective policies and strategies to minimise the risks of degrading the ancient sites and their environment, due to the ever-increasing mass tourism, over the last two decades.

The high increase in religious travellers has not only disrupted the lifestyle of villages around the ancient places, but also nature [76]. Santos Solla [77] already alerted to problems induced by tourism, such as overcrowding, deterioration of paths, and lack of economic opportunity, in many rural territories crossed by the Way. So, the efforts made by local/regional governments so far on the Way of Saint James the Great (Camino de Santiago) need to focus on preserving the future of the Twelve Ancient Paths of Guadalupe as main pilgrimage-touristic routes to the Royal Monastery.

\subsection{Environmental Aspects of Religious Travellers-The Sustainable Development of Nature (SDN)}

As the United Nations World Tourism Organisation (UNWTO) states, travel and tourism have recently been gaining importance in the global economy. According to the global gross domestic product (GDP), travel and tourism reached $9.8 \%$ in 2016 [78]. However, this rapid economic development has also had a negative impact on the ecosystem. It has gradually increased greenhouse gas emissions $\left(\mathrm{CO}_{2}\right)$ since 2005 [79]. Gössling [80] summarised the environmental consequences of tourism at a global scale in five main processes: changes in land-use/cover, use of energy, and different perspectives to understand nature as a psychological consequence of travel.

In the context of religious tourism, pilgrimages have been understood, for centuries, as a spiritual journey to satisfy inner needs by making a physical effort across environmental paths. This emerging perspective is contributing to the enhancement of sustainable forms of tourism. Sustainable Development of Nature (SDN) in religious tourism, therefore, includes not only strictly environmental activities, but social, economic, and cultural ones as well [81]. Religious travellers generate employment in rural communities [82] and prompt new development possibilities in remote villages. Nonetheless, Collins-Kreiner [83] advises about the effect of these religious journeys on the environment due to their large number of participants.

Religious tourism has also developed a Sustainable Development of Nature (SDN) through sustainable business models in isolated places based on the religious community tourism, for travellers seeking a place to rest along the paths towards the sacred place. This business model depends on travellers' stay in the villages located on the journey towards the final sacred destination $[84,85]$. In addition to travellers' accommodation expenditure, several factors must also be taken into account to realise how relevant religious travellers really are to the economy of the remote villages, along the religious path, in respect of, for example, average consumption at destination [86], quality of education [87], travel cost [88], and the price/accommodation ratio of the destinations [89]. The devoted faithful gather around divine, social, and cultural motivations to solve personal conflicts, either spiritual or secular [90], while engaging in these factors.

These factors have raised an environmental concern among tourist authorities due to the rapid increase of religious travellers in current times [91]. These concerns not only threaten the local communities who try to live up to these tourist activities, but also the integrity of environmental heritage, expressed through biological diversity in streams, rivers, and landscape, as well as 
ecological integrity against threat of pollution. Environmental sites around sacred places are currently facing several threats such as depletion of environmental resources, extinction of biodiversity and jeopardisation of the original landscape [92]. For instance, along the Camino de Santiago, the huge amount of different types of signs leading travellers along the path has inevitably changed the appearance of the landscape. Similarly, plastic objects discarded on the paths and rivers due to the gradually increasing of vending machines further spoils the original nature of the territory [93].

Broadly speaking, these challenges are directly related to economic growth, which negatively impacts on nature through the release of polluting emissions into the environment [94,95]. Unfortunately, very little has been done to implement Sustainable Development of Nature (SDN) within the environment, such as green policies [96]. As a result, environmental problems such as pollution of air, water, and soil warrant urgent attention [97].

Among these environmental concerns, several aspects can affect travellers' consciousness and this can also be generalised to society. 1 . The different assessments that individuals make to reduce the cost of utilities depends on the owner of such utilities. This leads to a gap between generating cost at home, when travelling, such as energy saving, recycling, discarding paper, and waste [98-100]. 2. The culture of impulsive and wasteful consumption based on the lack of sustainable awareness leads individuals to neither reuse nor recycle resources [101]. This counteracting culture already affects the entire planet and little advances have been made. 3 . The widespread culture of uncontrolled consumerism, based on the self-centred culture of instant gratification, that leads to high energy consumption and greenhouse gas emissions [102]. 4. The negative global mindset based on thinking that every environmental improvement by individuals is insignificant to improve nature [103,104].

From this perspective, Sustainable Development of Nature (SDN) must be based on being respectful to the natural environment as a collective good, which entails understanding nature as the heritage of humanity and everyone's responsibility, rather than short and partial solutions. Human flourishing and natural environment move hand in hand, which means that environmental and human issues should be attended at the same time. In other words, the ecological approach to nature is intertwined with the social approach.

Strategies to develop a natural harmony between nature and humans' impact in tourism should be promoted for environmental reasons, but also for sustainable social, cultural, and economic development of the area. Fortunately, sustainable perspectives of tourism are helping to reduce the human impact of tourist activities by balancing the needs of travellers and destinations, although concerns still remain [91]. In fact, Gupta [105] considers religious pilgrimages as a good example of sustainable tourism from an environmental point of view. Nevertheless, this work could be inspired in an idealised behaviour from Indian religious traditions not fully attributable to pilgrims of 21 st century.

\subsection{Human Dimension of Ecology—Environmental Human Development (EHD)}

Unfortunately, very little of sustainable tourism is applied to nature nowadays. An avid thirst for consumption is a dominating lifestyle in society, which is undoubtedly unsustainable for the population as a whole. On the one hand, theocentric religions are pushing in the right direction, these being understood as one of the most anthropocentric religions that promotes respect towards the environment among devoted individuals [106]; and on the other, the materialistic view of society pulled by an uncontrolled consumerism considers nature as a source for exploitation for their own benefit [102].

This dichotomy goes two ways for travellers. As a human being, they can be humanised or dehumanised depending on their respectful or disrespectful approach to environment [32]. This human dimension plays a key role in defining the human-nature relationship to attain real sustainable development through Environmental Human Development (EHD). Budeanu [107] highlighted the role played by tour operators in their capacity as enhancers of this human dimension of tourists, 
particularly in the largest ones of Europe, due to their influence on the change in behaviours and attitudes to environmental responsibility.

These human-nature relationships of Environmental Human Development (EHD) also involve protecting the cultural and architectural landmarks. In the context of the Royal Monastery of Santa María de Guadalupe and its Twelve Ancient Paths, numerous attractions and tourist and cultural paths can be highlighted. From a nature perspective, the land and subsoil offer diverse natural resources, especially in Villuercas-Ibores-Jara Geopark where the countryside and the natural resources are outstanding. From cultural and religious perspectives, relevant historical buildings are spread along those Twelve Ancient Paths.

This environmental relationship provides travellers with an opportunity to achieve authentic human development in nature by developing different measures to enhance the moral attitudes of humankind. One of these measures is promoting sustainable behaviour in public and private spaces by putting into effect eco-initiatives belonging to the role of a sustainable behaviour [108]. However, it is essential to turn to travellers and seek solutions to protect the natural systems and flourish the human being at the same time. Meaningful solutions rest on educational, social, and cultural actions [32]. It is critical to understand how to respect nature and contribute towards developing humankind by providing them the appropriate skills to take the right decisions in what concerns nature.

This responsibility can be seen from different perspectives such as: (1) participating in national or international fora to promote respect for nature [104]; (2) teaching others green manners to respect the environment [102] by avoiding leaving waste (papers, food, etc.) on sidewalks, rivers, or swamps; (3) being involved in local activities to defend the environment such as environmental-social campaigns, planting trees, cleaning streams and rivers, etc.

However, all those environmental advances that connect "religious consciousness" and "environmental awareness" need to be taught more efficiently through environmental educational programmes.

The challenges to make that connexion are twofold. First: To reduce the difference between the religious approach and the environmental educational programme [109]. Second: to improve the religious training among educators, given that they are not fully prepared to face the challenge.

In terms of the first issue, the biodiversity projects have set different ways of dealing with collision between religious and environmental perspectives. The intention of the project has been to put aside the possible clashes in approaching debates related to nature by showing respect toward religious educational programmes [73]. Likewise, religious approaches should avoid any controversial approach toward environmental education by stressing the stewardship perspective of nature [4]. This principle is proposed as one promising point of connection [109] as one of the key aspects of sustainable development [110].

From a religious consciousness perspective, environmental awareness is understood as a moral issue which has been a relevant theme of religious leaders' meetings in the last decades. Then, the necessary changes in pilgrims are focused on three aspects. First: Cognitive changes for learning what the religious leaders have taught recently to respect nature. Second: Affective and motivational changes, favouring the connection between religious consciousness and environmental awareness. Third: Changes on a behavioural level, by acquiring specific skills to respect nature by being more aware of the moral thoughts that remain inside [111].

All three of these changes can be taught in an educational environment. It is proposed to start with informal procedures in open spaces such as public parks or within ecotourism activities [112]. Among those activities, individuals are able take a more comprehensive attitude toward nature by considering the devastating human consequences to the environment [113]. In contrast, very little has been researched to ascertain the impact of those education programmes in urban settings or environmental paths [114]. Proactive education to respect nature can also enhance the biological diversity and resilience towards sacred places settings in rural areas [115]. 


\section{Materials and Methods}

\subsection{Descriptive Analysis}

This research used a questionnaire to analyse the effects of Religious Consciousness on Religious Travellers' Improved attitudes towards Nature. The paper also explores the influence of personal beliefs on raising environmental awareness due to the negative impact of humans on nature and human flourishing.

To aid the study, four constructs were designed: Religious Travellers' Improved Attitudes towards Nature (IAN), Sustainable Development of Nature (SDN), Environmental Human Development (EHD), and Religious Consciousness (RC). Referring to the adjective "Better, it can be understood within a range of dimensions in which attitudes are commonly evaluated as good-bad, or likable-unlikeable [116-118]. Related to those dimensions we have used the adjective "Better" to express the positive, the positive sign of relationships among variable.

The methods used in this paper are focused on the study of those attitudes, as a disposition of behaviour to solve environmental problems. In order to evaluate those attitudes, scales towards nature have been developed, correlating them with ecological behaviours. In our case, we have used Likert scales to measure the degree of importance they attach to certain environmental problems or others that are not environmental but that are directly or indirectly related. Then, the questionnaire was built based on a scale from 1 to 10 . Table 1 shows the constructs and the questions made.

Table 1. Latent variables obtained from the questionnaire.

\begin{tabular}{|c|c|c|c|}
\hline Constructs & Indicator & Question & Authors \\
\hline $\begin{array}{l}\text { Improved Attitudes } \\
\text { towards Nature }\end{array}$ & $\begin{array}{l}\mathrm{IAN}_{1} \\
\mathrm{IAN}_{2} \\
\mathrm{IAN}_{3}\end{array}$ & $\begin{array}{l}\text { Do you think it is important to understand nature as the } \\
\text { heritage of humanity and something everyone should be } \\
\text { responsible for? } \\
\text { Do you think it is important to connect respect for nature with } \\
\text { social, cultural and economic development? } \\
\text { Do you think it is important to reduce human impact by } \\
\text { treating nature as a direct manifestation of God? }\end{array}$ & [45] (p. 81), [91] \\
\hline $\begin{array}{c}\text { Religious } \\
\text { Consciousness }\end{array}$ & $\begin{array}{l}\mathrm{RC}_{1} \\
\mathrm{RC}_{2} \\
\mathrm{RC}_{3} \\
\mathrm{RC}_{4} \\
\mathrm{RC}_{5}\end{array}$ & $\begin{array}{l}\text { Do you think it is important to realise that humans do not } \\
\text { own nature; rather, it is the divine creator that encourages us } \\
\text { to protect it? } \\
\text { Do you think it is important to have moral guidance to } \\
\text { contrast your environmental actions? } \\
\text { Do you think it is important to be inspired by the values of } \\
\text { meaningful sacred books? } \\
\text { Do you think it is important to seek God everywhere } \\
\text { in nature? } \\
\text { Do you think it is important to promote admiration } \\
\text { towards nature? }\end{array}$ & {$[8,15,40,41,119,120]$} \\
\hline $\begin{array}{c}\text { Sustainable } \\
\text { Development of } \\
\text { Nature }\end{array}$ & $\begin{array}{l}\mathrm{SDN}_{2} \\
\mathrm{SDN}_{3}\end{array}$ & $\begin{array}{l}\text { Do you think it is important to stop uncontrolled } \\
\text { consumerism that does not respect nature? } \\
\text { Do you think it is important to behave the same way when } \\
\text { using private or public utilities to avoid generating additional } \\
\text { cost or respect public goods? } \\
\text { Do you value individual environmental measures aimed at } \\
\text { protecting the environment? }\end{array}$ & {$[98-102,104]$} \\
\hline $\begin{array}{c}\text { Environmental } \\
\text { Human } \\
\text { Development }\end{array}$ & $\begin{array}{l}\mathrm{EHD}_{1} \\
\mathrm{EHD}_{2} \\
\mathrm{EHD}_{3}\end{array}$ & $\begin{array}{l}\text { Do you think it is important to participate in national or } \\
\text { international fora to promote respect for nature? } \\
\text { Do you think it is important to teach other individuals or } \\
\text { communities green manners to respect the environment? } \\
\text { Do you think it is important to be involved in local } \\
\text { environmental activities to defend the environment? }\end{array}$ & {$[100,104]$} \\
\hline
\end{tabular}

The original sample was 260 individuals. Following Hair et al. [121], if data not valid for observation in a questionnaire exceeded 15\% (blank answers due to lack of information), the questionnaire in question must be excluded from the dataset. In our case, 18 questionnaires did not fulfil this feature and were eliminated. 
Pilgrims usually visit sacred places based on their religiosity, seeking the intercession of God, particularly in undercrowded religious destinations (e.g., Guadalupe). However, there are other cultural motivations where travellers seek other types of experiences not based on religion [122]. Pilgrimage has, therefore, become a cultural product [90]. In our case, whereas $84 \%$ of those travellers visited the Royal Monastery for religious purposes, only $16 \%$ did so for tourist or sightseeing reasons. The research population was 203 visitors. The interviews were made in summertime due to the influx of tourists. Two places were selected to make the interviews, first the entrance of the sacred place and secondly, the Local Tourist Office (Appendix A). Since 71\% of the tourists interviewed were Catholic, $19 \%$ Protestant Church, and 10\% other faiths, we focused the paper on Christianity.

Five qualitative interviews were made to validate the questionnaire. Through two focus groups, relevant stakeholders were involved in the process of validation conducted to two focus groups organised in June 2017 involving important stakeholders belonging to the private and public sectors. In Figure 1 is shown the conceptual diagram of the structural equation model utilised.

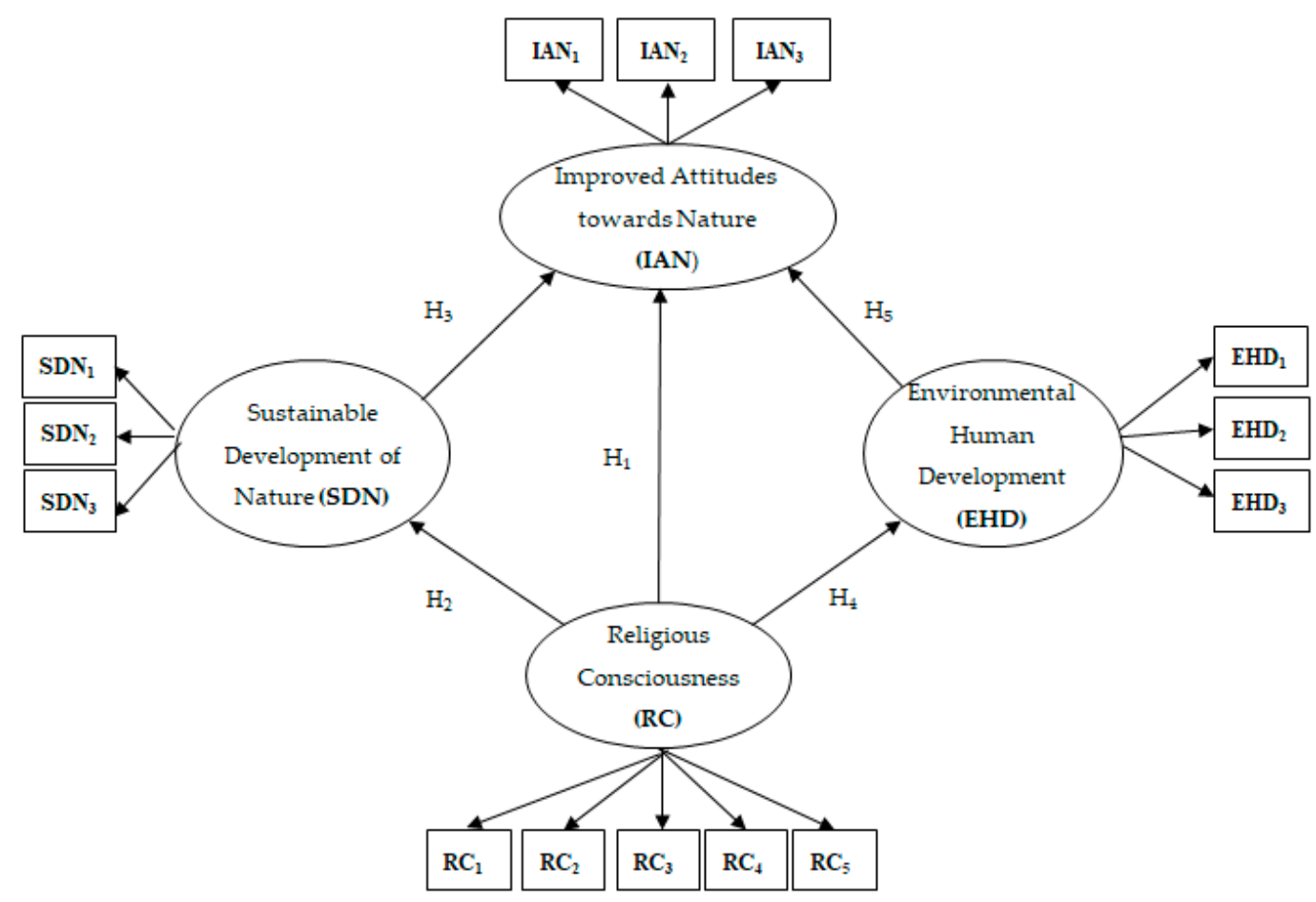

Figure 1. Conceptual diagram of the structural equation model utilised.

\subsection{Conceptual Framework and Model Specification}

This study establishes five hypotheses to gain further insight into the role that Religious Consciousness plays in the existing relationships system. The hypotheses are:

1. $\mathrm{H}_{1}$-Religious Consciousness (RC) positively influences Religious Travellers' Attitude towards Nature (IAN).

2. $\mathrm{H}_{2}$-Religious Consciousness (RC) positively influences Sustainable Development of Nature (SDN).

3. $\mathrm{H}_{3}$-Sustainable Development of Nature (SDN) positively influences Religious Travellers' Attitude towards Nature (IAN).

4. $\mathrm{H}_{4}$-Religious Consciousness (RC) positively influences Environmental Human Development (EHD).

5. $\mathrm{H}_{5}$-Environmental Human Development (EHD) positively influences Religious Travellers' Attitude towards Nature (IAN). 


\subsection{Data Processing}

Researchers especially follow SEM's capacity to assess constructs, this method provides them with an option to link nonobservable variables to indicators on a theoretical level [123]. Using the Structural Equation Modelling (SEM), it is important to be aware not only of methodologies based on Covariance Based-Structural equation modeling (CB-SEM) [124] but on the variance as well Structural equation modeling-Partial Least Square SEM-PLS [125,126]. Then, due to the statistical inconvenience presented by the CB-SEM, a new methodology was delivered. Focus on prediction, PLS-SEM Path Modelling provides you with a structural model to ascertain and predict relationship among latent variables (e.g., [127]). The methodological concepts underlying both approaches have been compared in several publications, including those by Chin and Newsted [128], Hair et al. [121], and Lohmöller [125].

While CB-SEM provides confident information of the structural model under certain conditions [129], PLS-SEM Path Modelling can be used either for reflective and formative measures [128]. Furthermore, PLS-SEM provides you with reliable information without any constraint in complex model [121]. This complexity among latent variables and observable indicators is solved through Structural Equation Modelling (SEM) $[38,130]$. This statistical method combines relationships between exogenous variables-known as independent-and endogenous-or dependent-variables [131]. Also, PLS-SEM modelling enables developing iterative and non-iterative structural models [132].

\section{Structural Equation Modelling Results}

\subsection{Assessment of Measurement Model}

\subsubsection{Reliability and Validity}

The reliability and validity conditions of the reflective items are established in three steps: First. The individual reliability of the model is checked. Second. The construct reliability is measured through the Composite Reliability (CR), Cronbach's Alfa and rho A. Third. The convergent validity is assessed by the Average Variance Extracted (AVE).

First: The individual reliability of the model is accepted when the loadings of the items from each latent variable are higher than 0.7. Table 2 shows that loadings fulfil this requirement whether they refer to Improved Attitudes towards Nature (IAN), Sustainable Development of Nature (SDN), Environmental Human Development (EHD) or Religious Consciousness (RC).

Second: Construct reliability and convergent validity are addressed to assess the internal consistency. In construct reliability, reiterated versions correlate to evaluate the consistency of the indicators. The consistency of the indicators depends on the level of agreement of observers through different test items that prove that the same latent variable generates similar results. It assesses how strong each item is in relation with the corresponding latent variables [127]. The results indicate that reflective constructs are reliable, expressed as indicator loads $(\lambda)$, and Composite Reliability (CR) is greater than 0.7 with respect to its respective construct [38]. Cronbach's Alpha and Rho A tests is the coefficients used from spearman's test. It measures the efficacy of the constructs. Through the Composite Reliability (CR), constructs can be validated in as much as its value is higher than 0.7 [133].

Third: While reliability is essential, itself alone is not enough. It needs to be valid. Validity ensures that what is being measured is correct, i.e., the latent variable. Convergent validity assesses how its latent variable is related to its indicators. The variance of the items is explained through the Average Variance Extracted (AVE). Using the same basis as that used with the individual indicators, an AVE value of $50 \%$ or higher means that, on average, construction accounts for more than half of the variance of its own indicators. The value must be greater than 0.5 [38]. The latent variables exceed this value (Table 2). 
Table 2. Loads $(\lambda)$ of the item with the construct.

\begin{tabular}{ccccccc}
\hline $\begin{array}{c}\text { Latent } \\
\text { Variables }\end{array}$ & Indicator & Loadings & $\begin{array}{c}\text { Cronbach's } \\
\text { Alpha }\end{array}$ & Rho_A & $\begin{array}{c}\text { Composite } \\
\text { Reliability }\end{array}$ & $\begin{array}{c}\text { Average Variance } \\
\text { Extracted (AVE) }\end{array}$ \\
\hline Better Attitude & $\mathrm{IAN}_{1}$ & 0.817 & 0.847 & 0.850 & 0.907 & 0.766 \\
towards Nature & $\mathrm{IAN}_{2}$ & 0.851 & & & & \\
$\mathrm{IAN}_{3}$ & 0.743 & & & 0.876 & 0.702 \\
Sustainable & $\mathrm{SDN}_{1}$ & 0.700 & 0.787 & 0.790 & & \\
Development of & $\mathrm{SDN}_{2}$ & 0.759 & & & 0.698 \\
Nature & $\mathrm{SDN}_{3}$ & 0.776 & & & & \\
\hline Environmental & $\mathrm{EHD}_{1}$ & 0.724 & 0.783 & 0.781 & & \\
Human & $\mathrm{EHD}_{2}$ & 0.723 & & & 0.696 \\
Development & $\mathrm{EHD}_{3}$ & 0.762 & & & & \\
\hline & $\mathrm{RC}_{1}$ & 0.785 & 0.889 & 0.903 & & \\
Religious & $\mathrm{RC}_{2}$ & 0.797 & & & & \\
Consciousness & $\mathrm{RC}_{3}$ & 0.812 & & & & \\
& $\mathrm{RC}_{4}$ & 0.928 & & & & \\
\hline
\end{tabular}

Rho_A tests is the coefficients used from spearman's test. It measures the efficacy of the constructs.

\subsubsection{Discriminant Validity}

Discriminant validity expresses how each latent variable is different from others within the model [131]. A fairly recent criterion is used to measure discriminant validity: the heterotrait-monotrait ratio of correlations (HTMT). To clearly discriminate between two factors, the HTMT should be significantly less than one [132]. Its value should be smaller than 0.85 , otherwise the correlation between constructs is not significant [132]. In this case, all the data are below (see Table 3).

Table 3. Heterotrait-Monotrait Ratio (HTMT).

\begin{tabular}{ccccc}
\hline & IAN & SDN & EHD & RC \\
\hline IAN & & & & \\
SDN & 0.752 & & & \\
EHD & 0.739 & 0.556 & & \\
RC & 0.723 & 0.655 & 0.555 & \\
\hline
\end{tabular}

\subsection{The Structural Model Assessment}

\subsubsection{The Predictive Model}

Coefficient of determination $\left(\mathrm{R}^{2}\right)$ determines the prediction of the model. It means the amount of variance explained by the construct within the model. $R^{2}$ is strong, moderate, and weak when the values are higher than $0.67,0.33$, and 0.19 , respectively [134].

Table 4 reports the variance explained $\left(R^{2}\right)$. The model explained $75.6 \%$ of the total variance. So, $R^{2}$ has a strong predictive power. Thus, our four latent variables (Improved Attitudes towards Nature (IAN), Sustainable Development of Nature (SDN), Environmental Human Development (EHD) or Religious Consciousness (RC)) strongly explain $75.6 \%$ of the variance of the total Religious Traveller's Attitudes towards Nature. Similarly, Religious Consciousness (RC) explains $43.1 \%$ of the variance of Sustainable Development of Nature (SDN) and 32.1\% of the variance of Environmental Human Development (EHD). 
Table 4. Value of endogenous variables.

\begin{tabular}{ccc}
\hline & $\mathbf{R}^{\mathbf{2}}$ & $\mathbf{Q}^{\mathbf{2}}$ \\
\hline AN & 0.756 & 0.413 \\
SDN & 0.431 & 0.198 \\
EHD & 0.321 & 0.144 \\
RC & - & - \\
\hline
\end{tabular}

In addition, the predictive relevance $\left(\mathrm{Q}^{2}\right)$ is calculated for the Stone-Geisser test and for the latent variables that predict "cross-validated redundancy" [135]. There is relevance prediction if $\mathrm{Q}^{2}>0$, and in this case, our dependent variable (RT) has considerable predictive relevance. Table 4 shows that all the constructs (Improved Attitudes towards Nature (IAN), Sustainable Development of Nature (SDN), Environmental Human Development (EHD), or Religious Consciousness (RC)) fulfil this requirement.

\subsubsection{Significance of Structural Model Path Coefficients}

Standardised path coefficients $(\beta)$ measure if the variance of exogenous variable explains appropriately the endogenous variables [135]. Chin [134] suggests that path coefficient must be higher than 0.2. As Figure 2 shows, Religious Consciousness (RC) positively influences several variables, such as Improved Attitudes towards Nature (IAN), Sustainable Development of Nature (SDN), and Environmental Human Development (EHD). All the hypotheses are significant as well as supported with a $99.9 \%$ confidence level.

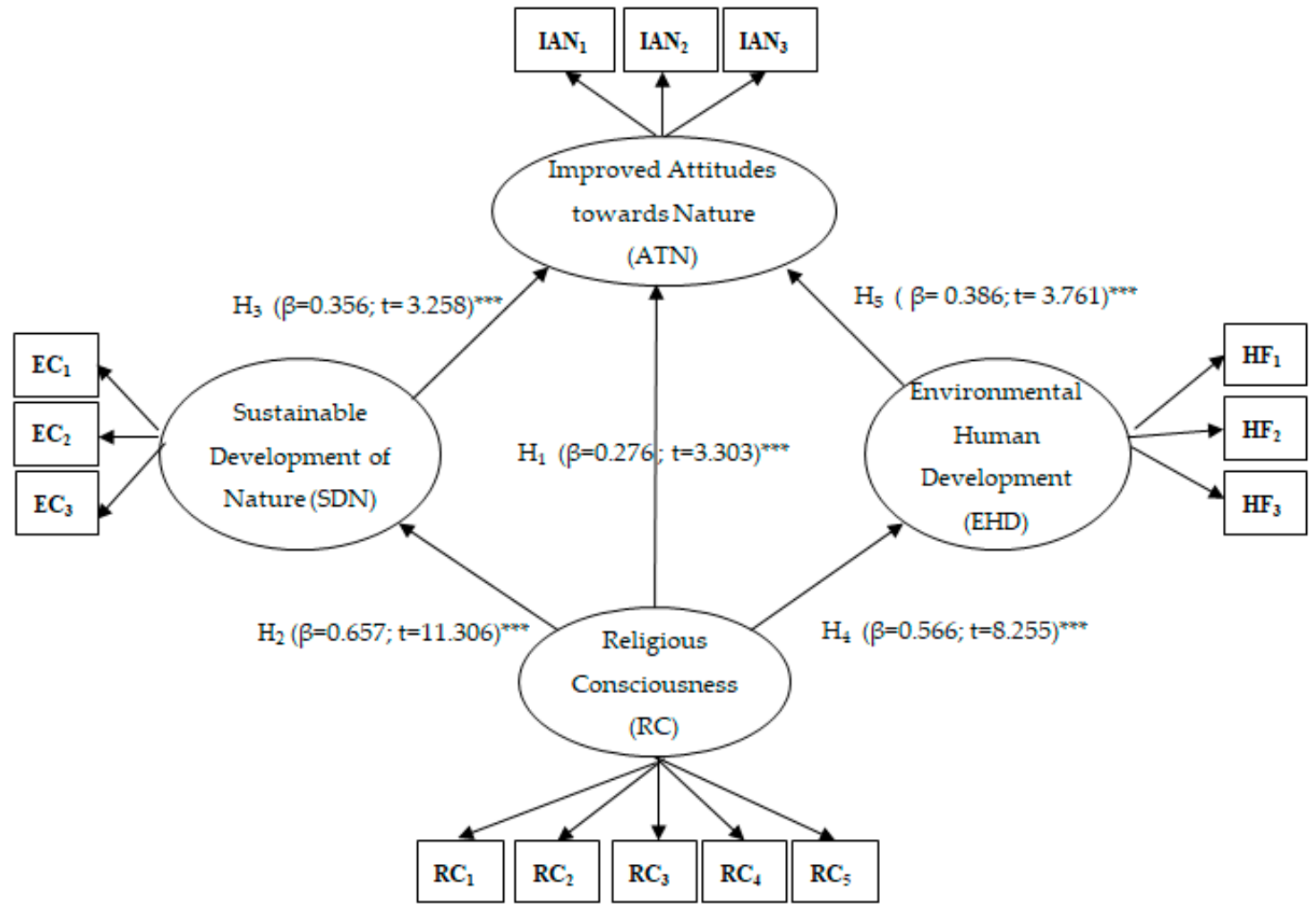

Figure 2. Significance of structural model path coefficients, at $95 \% *, 99 \%{ }^{* *}$, and $99.9 \% * * *$, respectively.

Confidence intervals and t-values are measured in Table 5. It provides you with a second test of assessing the significance of the path coefficient. The measure is based on analysing each interval, which cannot contain a zero [132]. This test confirms the statistical tests of the path coefficient. 
Table 5. Coefficients path and statistical significance.

\begin{tabular}{|c|c|c|c|c|c|c|}
\hline \multicolumn{2}{|c|}{ Hypotheses } & \multirow{2}{*}{\begin{tabular}{|l|}
$5.0 \%$ \\
0.137
\end{tabular}} & \multirow{2}{*}{\begin{tabular}{|c|}
$\mathbf{9 5 . 0} \%$ \\
0.398
\end{tabular}} & \multirow{2}{*}{$\begin{array}{c}\beta \\
0.276\end{array}$} & \multirow{2}{*}{$\begin{array}{c}\text { T Statistics } \\
3.303\end{array}$} & \multirow{2}{*}{$\frac{p \text { Values }}{0.000^{* * *}}$} \\
\hline $\mathrm{H}_{1}$ & $\mathrm{RC} \rightarrow \mathrm{IAN}$ & & & & & \\
\hline $\mathrm{H}_{2}$ & $\mathrm{RC} \rightarrow \mathrm{SDN}$ & 0.563 & 0.750 & 0.657 & 11.306 & $0.000^{* * *}$ \\
\hline $\mathrm{H}_{3}$ & $\mathrm{SDN} \rightarrow \mathrm{IAN}$ & 0.174 & 0.586 & 0.356 & 3.258 & $0.000^{* * *}$ \\
\hline $\mathrm{H}_{4}$ & $\mathrm{RC} \rightarrow \mathrm{EHD}$ & 0.456 & 0.680 & 0.566 & 8.255 & $0.000^{* * *}$ \\
\hline $\mathrm{H}_{5}$ & $\mathrm{EHD} \rightarrow \mathrm{IAN}$ & 0.224 & 0.561 & 0.386 & 3.761 & $0.000^{* * *}$ \\
\hline
\end{tabular}

\section{Discussion}

Due to the gradual increase of religious tourism, environmental paths receive many travellers crossing bridges, landscapes, pastures, etc., inevitably impacting on the ecosystem in one way or another [79]. From this perspective, it is important to analyse how religious consciousness drives them to behave respectfully towards nature. In spite of some studies, difficulty has arisen to know if devoted believers can be more or less respectful to nature [8].

Religious approaches of devoted Christians' perception of nature were researched in the paper. As the results have shown, $75.6 \%$ of Religious Travellers' Improved Attitudes towards Nature can be explained by the model presented. This means that not only does Religious Consciousness (RC) inspire devoted faithful to be more respectful to the environment, but also they agree with the sustainable measures proposed in the model for religious tourism through Sustainable Development of Nature (SDN).

The model also shows that environmental relationship provides travellers with the opportunity to achieve an authentic human development in nature by defining the human-nature relationship to attain a real sustainable development through Environmental Human Development (EHD). According to Chin and Newsted [128], the model is strongly predictive. It can allow decision-makers to establish environmental strategies based on the effect of religious practices and allow pilgrims to develop human capabilities and attitudes to respect nature, by developing a common language between science and religion among religious travellers. On the side of religion, the model can help shape attitudes and action to develop a broader commitment to environmental protection and restoration [63]. On the side of environmentalist, the model can also help to shape environmental attitudes to connect with religion [71] to understand the world beyond everyday experiences [59].

As a result, on one side, religious consciousness $(\mathrm{RC})$ provides improved attitudes towards nature through Sustainable Development of Nature (SDN). It means that $43.1 \%$ of those environmental attitudes to respect nature are due to the influence of religious awareness on travellers' environmental decision. Then, religion and spirituality can transform individuals to channel improved attitudes toward nature [61,62], by developing several sustainable measures to protect the environment. It explains that religious awareness helps pilgrims toward the Royal Monastery of Guadalupe to be more respectful to the environment, balancing the current concern of tourism authorities that travellers threaten nature [91]. Those results shed light on other studies that produced opposite conclusions [2,51-53].

On the other side, Religious Consciousness (RC) provides improved attitudes towards nature through Environmental Human Development (EHD). It means that $32.1 \%$ of those environmental attitudes to respect nature come from Religious Consciousness. This human dimension plays a key role in defining the human-nature relationship to attain real sustainable development through Environmental Human Development (EHD), especially in pilgrims who visit the Real Monastery of Guadalupe [107].

These human-nature relationships of Environmental Human Development (EHD) are important to protect nature in general, but also the Twelve Ancient Paths in particular by participating in national or international fora, teaching in communities, or being involved in local environmental activities 
to defend the environment. Paths modelling in the paper validate all the hypotheses. It means that within a $99.9 \%$ interval of confidence, the results express the very significant relationships in terms of variance among the constructs designed [135]. Among the hypotheses, $\mathrm{H}_{2}(\beta=0.657 ; \mathrm{t}=11.306)$ and $\mathrm{H}_{4}(\beta=0.566 ; \mathrm{t}=8.255)$ are the strongest. Religious Consciousness $(\mathrm{RC})$ strongly affects the Sustainable Development of Nature (SDN) and Environmental Human Development (EHD). Pilgrims strongly link religion with environment. Integrating respect for nature, either from the secular or religious side, has been the intention of religious initiatives over the past decades. Although results among tourists who visited the Royal Monastery through the ancient path of Guadalupe should be treated with prudence, they can also be interpreted as a shift in the Christian attitudes towards nature.

The religious and moral dimension of travellers has, therefore, become a key factor to promote respectful behaviour towards nature. These conclusions are well aligned with the Bible, which perceives the environment as something worthy of protection and preservation [5]. As can be seen from the results, travellers on their way towards the sacred monastery in Guadalupe consider themselves stewards of nature, being entrusted with the environmental legacy they have received from the Divine Creator.

However, those results cannot be extrapolated to all religious travellers who visit the Royal Monastery of Guadalupe and other sacred places, such as Camino de Santiago, but they can lead us in the way of promoting environmental awareness among religious pilgrims. Even though this research is a push in the right direction [106], the materialistic view of society pulled by an uncontrolled consumerism considers nature as a source for exploitation to their own benefit [103]. That is why individuals can be humanised or dehumanised depending on their respectful or disrespectful approach to environment [32].

The outcome of this research can guide Religious Travellers' improved attitudes to face the environmental concerns of society positively in three different ways. First: Make the most of energy saving, treat the paper and waste [98-100] in nature as you would at home. Second: Fight the culture of impulsive and wasteful consumption by making an effort to recycle resources [101] and make a rational consumption of energy and reduce greenhouse gas emissions [102]. Third: Give value to each small effort individuals make in benefit of nature as little as it may be $[103,104]$. Results show a flourishing of human, by developing the religious consciousness to respect nature and natural environment, move hand in hand. This human dimension plays a key role in defining the human-nature relationship to attain real sustainable development.

The findings of this study help us to understand the factors that have the most significant effect on developing the Improved Attitudes towards Nature (IAN) spectrum through the mediation effect of Religious Consciousness (RC) on Improved Attitudes towards Nature. Through this mediation, Sustainable Development of Nature (SDN) or Environmental Human Development (EHD) sheds light on the sheer effect of exogenous variables (RC, EHD, and SDN) on endogenous ones (IAN). This paper also offers a new outlook to help design strategies to promote improved behaviour among Religious Travellers.

The bottom line of the study is that the indirect effect of Religious Consciousness (RC) on Improved Attitude towards Nature (IAN) through Sustainable Development of Nature (SDN) $\left(\mathrm{H}_{2} \times \mathrm{H}_{3}\right.$ ) $(0.657 \times 0.356=0.233)$ is likely to increase Improved Attitude towards Nature (IAN) indirectly by 0.233 . However, the total impact of Religious Consciousness (RC) on Improved Attitude towards Nature (IAN) increases to 0.509 , calculated by adding the direct impact of Religious Consciousness (RC) on Improved Attitude towards Nature (IAN): $0.276+0.657 \times 0.356=0.509$.

Likewise, the indirect effect of Religious Consciousness through Environmental Human Development (EHD) $\left(\mathrm{H}_{4} \times \mathrm{H}_{5}\right)(0.566 \times 0.386=0.212)$ is likely to increase Improved Attitude towards Nature (IAN) indirectly by 0.212 . The total impact of Religious Consciousness (RC) increases to 0.488 , calculated by adding the direct impact of Religious Consciousness (RC) on Better Attitude towards Nature (IAN): $0.276+0.566 \times 0.386=0.488$. 
Religious Consciousness (RC), therefore, influences Improved Attitude towards Nature (IAN) more positively by promoting direct education against environmental threats, by stopping the uncontrolled consumerism or saving energy and recycling (SDN) rather than organising indirect environmental training and educational activities by enhancing the involvement of Religious Travellers (EHD). However, both actions are necessary to protect the environment along the paths that end up in the Royal Monastery of Guadalupe.

As results, we have shown that RC influences IAN. In the recent context of religious leaders' meetings, respect for nature is playing a relevant role. Through the religious leaders' environmental agenda, important decisions have been taken but changes have to occur in the thousands of pilgrims who visit the sacred places daily. By cognitive, affective, motivational, and behavioural changes in pilgrims, improved attitudes toward nature can occur. Finding the connection between ecologist and religious leaders, environmental education can spread the commitment signed on International Environmental meetings about the thousands of pilgrims who frequently visit the sacred places in general and the Royal Sanctuary of Guadalupe in particular.

We would like to point out the following limitations of the study: First of all, the paper is dealing with intangibles such as Improved Attitudes towards Nature (IAN), Religious Consciousness (RC), the Sustainable Development of Nature (SDN) to protect the environment and the promotion of Environmental Human Development (EHD) through environmental education and activities. Moreover, Improved Attitudes towards Nature (IAN) can be understood from different angles and perspectives depending on the environmental background of each pilgrim who answer the questionnaire. Also, Religious Consciousness (RC) can be assessed differently according to the level of religious commitment of each pilgrim. Environmental Human Development (EHD) can be related also to social, psychological, and economic fields, so it would be fine to have explained in detail to every tourist the holistic meaning of that development.

The second limitation is that it is difficult to isolate the Religious Consciousness (RC) from other aspects to measure its effect on Improved Attitudes towards Nature (IAN). Those factors can be either personalised or generalised: the educational background, the uncontrollable growth of many cities which causes much pollution, the media and digital world; the new cultural and ecological trends in cultures, the group of interest whether they are based on economic, technological, or financial attitudes. All of those aspects can affect Improved Attitudes towards Nature (IAN) and indirectly the other variables explained in the model.

The third one can be the lack of successful experiences to highlight among pilgrims to compare, as a practical (not theoretical) example of achieving authentic human development in nature and its influence in their moral structure. Further research must be done in this regard.

Added to the last two aspects, in the fourth stage, we dare to say that this is the first research that analyses sustainable aspects that connect religiosity and nature. For this reason, ongoing work should be put into cautious view, as manifested in other touristic destinations.

Other limitations of this research can be found. The fifth limitation can be drawn from the questionnaires collected at the end of the pilgrimage journey's stage. The data was collected in the summer of 2017. Under the circumstances, it would have been preferable to have collected the data throughout the year. It would have guaranteed more reliable and valid data collection. Future studies might explore pilgrims' experiences during the year.

The sixth limitation refers to the environmental experience of nature that tourists had. Not all of the pilgrims came on foot through the ancients paths of the Royal Monastery of Guadalupe, some of them came by bus or car almost to the Monastery. So the experienced sensations over an enduring journey and the impact of nature on pilgrims were not the same. A prospective future study will overcome this limitation. This values further research about visiting the Real Monastery of Guadalupe through the Twelve Ancient Paths. Finally, it is critical for pilgrims to understand how to respect nature and contribute towards developing humankind by providing them with the appropriate skills to take the right decisions in what concerns nature. 


\section{Conclusions}

Despite the religious awareness and the lessons we have been taught for centuries regarding living in harmony with the environment, little research has actually been conducted in the field of Religious Travellers to provide efficient tools to address the current environmental threats of nature or improve the human capabilities to protect the environment.

According to the results, Religious Consciousness (RC) positively influences Sustainable Development of Nature (SDN) and Environmental Human Development (EHD) with the aim of providing Religious Travellers with an Improved Attitude towards Nature (IAN). Travellers on their way towards the revered monastery in Guadalupe have internalised not only the inspiring behaviour drawn from the Bible, but also the affective and meaningful examples to look at nature as a creature to be respected. For these travellers, nature is a gift given by the Divine Creator that deserves to be treated with admiration.

This view makes it easier for travellers to act responsibly to protect nature through Sustainable Development of Nature (SDN). Travellers then undertake environmental measures to protect the environment such as: stopping the uncontrolled consumerism by avoiding unreasonable cost in public spaces compared to private spheres and raising individual awareness to be more environmentally responsible. Similarly, travellers' religious beliefs help them be proactive in developing their human capabilities by participating in environmental fora, seminars, etc.

Even though the results do not reveal the type of mediation between Religious Consciousness (RC) and Religious Travellers' Improved Attitude towards Nature (IAN), it is essential to highlight that the total effect over Sustainable Development of Nature (SDN) and Environmental Human Development (EHD) is quite high. This is something that will be analysed in further research nonetheless. Presumably, Religious Consciousness most likely mediates other constructs.

Concerning explained variance, Sustainable Development of Nature (SDN) alone explains $43.1 \%$ of the total information provided in the model. In other words, if this construct were the only one within the model, the variance explained $\left(R^{2}\right)$ would have been "moderate". Therefore, for Religious Travellers, their belief alone would almost suffice to address the environmental side. Likewise, Environmental Human Development (EHD) explains 32.1\% of the total information. Human flourishing is also a strong factor to develop Improved Attitudes towards Nature.

Based on the predictive model, both constructs move together. Environmental and human aspects are aligned simultaneously. In other words, the ecological approach to nature is intertwined with the social approach.

Notwithstanding the methodology applied to provide consistent results among religious tourists who visited the Royal Monastery through the ancient path of Guadalupe, the findings should be processed and understood with caution. Ongoing studies should be put into cautious view, as manifested in other destinations, such as the Way of Saint James. The contrasted findings should be compared with the new ones.

Regarding questions included in the questionnaire, they were previously validated in some personal interviews with key informants. However, we think that in future surveys more efforts should be made in order to standardise how the questions must be formulated and to make a classification based on typologies of pilgrims (means of transport, excursion trips, etc.).

All these abovementioned limitations will be overcome in further research about religious travellers to the revered monastery in Guadalupe.

Author Contributions: R.R.R. wrote the paper. M.P.F. revised and corrected it.

Funding: This research was funded by INTERRA (Research Institute for Sustainable Territorial Development) which belong to the University of Extremadura.

Acknowledgments: We would like to especially thank Marlene de Witt and Brian Adams for correcting the English language. We are also grateful to the editors and anonymous reviewers for their useful comments, suggestions and corrections. 
Conflicts of Interest: The authors declare no conflict of interest.

\section{Appendix}

Table A1. Demographic information.

\begin{tabular}{|c|c|c|}
\hline Information & $\mathrm{N}=242$ & Percentage $(\%)$ \\
\hline \multicolumn{3}{|l|}{ Reasons for travelling } \\
\hline Religious & 203 & 84 \\
\hline Touristic & 39 & 16 \\
\hline Total & 242 & $100 \%$ \\
\hline \multicolumn{3}{|l|}{ Gender } \\
\hline Male & 108 & 44.6 \\
\hline Female & 134 & 55.4 \\
\hline Total & 242 & $100 \%$ \\
\hline \multicolumn{3}{|l|}{ Age } \\
\hline 25 years or younger & 46 & 19.0 \\
\hline $26-44$ years old & 82 & 33.9 \\
\hline $45-59$ years old & 65 & 26.9 \\
\hline 60 years old and above & 49 & 20.2 \\
\hline Total & 242 & $100 \%$ \\
\hline \multicolumn{3}{|l|}{ Type of visitor } \\
\hline Single & 25 & 10.3 \\
\hline Family and/or friends with children & 80 & 33.1 \\
\hline Family and/or friends without children & 137 & 56.6 \\
\hline Total & 242 & $100 \%$ \\
\hline \multicolumn{3}{|l|}{ Main occupation } \\
\hline Student & 31 & 12.8 \\
\hline Working in the public sector & 69 & 28.5 \\
\hline Working in the private sector & 76 & 31.4 \\
\hline Other & 66 & 27.3 \\
\hline Total & 242 & $100 \%$ \\
\hline \multicolumn{3}{|l|}{ Language } \\
\hline Spanish & 149 & 61.6 \\
\hline English & 31 & 12.8 \\
\hline French & 19 & 7.9 \\
\hline Portuguese & 15 & 6.2 \\
\hline Italian & 11 & 4.5 \\
\hline Other & 17 & 7.0 \\
\hline Total & 242 & $100 \%$ \\
\hline
\end{tabular}

\section{References}

1. Gardner, G.T.; Stern, P.C. Environmental Problems and Human Behavior; Allyn \& Bacon: Needham Heights, MA, USA, 1996.

2. Morrison, M.; Duncan, R.; Parton, K. Religion does matter for climate change attitudes and behavior. PLoS ONE 2015, 10, e0134868. [CrossRef] [PubMed]

3. Djupe, P.A.; Hunt, P.K. Beyond the Lynn White thesis: Congregational effects on environmental concern. J. Sci. Study Relig. 2009, 48, 670-686. [CrossRef]

4. Kearns, L. Saving the creation: Christian environmentalism in the United States. Sociol. Relig. 1996, 57, 55-70. [CrossRef]

5. Tarakeshwar, N.; Swank, A.B.; Pargament, K.I.; Mahoney, A. The sanctification of nature and theological conservatism: A study of opposing religious correlates of environmentalism. Rev. Relig. Res. 2001, 42, 387-404. [CrossRef]

6. Boff, L. Liberation and Ecology; Orbis Books: Maryknoll, NY, USA, 1995. 
7. Palmer, M. Alliance of Religions and Conservation; ARC Press: Bath, UK, 2008.

8. Holland, A. The value space of meaningful relations. In Human-Environment Relations: Transformative Values in Theory and Practice; Brady, E., Phemister, P., Eds.; Springer: Dordrecht, The Netherlands, 2012; pp. 3-15.

9. Smart, N. The Religious Experience of Mankind; Charles Scribner's Sons: New York, NY, USA, 1969.

10. Lombaard, C. Spirituality: Sense and gist. On meaning, God and being. Acta Theol. 2008, 1, 94-107.

11. Northcott, M. Loving scripture and nature. J. Study Relig. Nat. Cult. 2009, 3, 247-253. [CrossRef]

12. Delio, I. Is Natural Law “Unnatural?" Exploring God and Nature Through Teilhard's Organic Theology. Theol. Sci. 2017, 15, 276-288. [CrossRef]

13. White, L. Of our ecological crisis. In Earthcare: An Anthology in Environmental Ethics; Clowney, D., Mosto, P., Eds.; Rowman \& Littlefield: Lanham, MD, USA, 2009; pp. 55-62.

14. Nash, R.F. The Rights of Nature: A History of Environmental Ethics; The University of Wisconsin Press: Madison, WI, USA, 1989.

15. Timothy, D.; Olsen, D. Tourism, Religion and Spiritual Journeys; Routledge: London, UK, 2006; Volume 4.

16. Buzinde, C.N.; Kalavar, J.M.; Kohli, N.; Manuel-Navarrete, D. Emic understandings of Kumbh Mela pilgrimage experiences. Ann. Tour. Res. 2014, 49, 1-18. [CrossRef]

17. Edensor, T. Performing tourism, staging tourism: (Re) producing tourist space and practice. Tour. Stud. 2001, 1, 59-81. [CrossRef]

18. Crémoux, F. Pèlerinages et Miracles: À GUADALUPE au XVIe Siècle; Casa de Velázquez: Madrid, Spain, 2001; Volume 17.

19. Peterson, J.F. Creating the Virgin of Guadalupe: The cloth, the artist, and sources in sixteenth-century New Spain. Americas 2005, 61, 571-610. [CrossRef]

20. Taylor, W.B. The Virgin of Guadalupe in New Spain: An inquiry into the social history of Marian devotion. Am. Ethnol. 1987, 14, 9-33. [CrossRef]

21. Tormo, E. Monasterio de Guadalupe; Hijos de, J., Ed.; Thomas: Madrid, Spain, 1950.

22. Pulido Fernández, M.; Lagar Timón, D.; García Marín, R. El geoturismo como estrategia de desarrollo en áreas deprimidas: Propuesta de Geoparque Villuercas, Ibores, Jara (Extremadura). Boletín de la Asociación de Geógrafos Españoles 2011, 56, 485-498.

23. Nasr, H.; Nasr, S.H. Religion \& the Order of Nature; Oxford University Press: New York, NY, USA, 1996.

24. Townsend, P.K. Environmental Anthropology: From Pigs to Policies; Waveland Press: Long Grove, IL, USA, 2017; Volume 10.

25. Clark, E.T. The Psychology of Religious Awakening; Macmillan: Oxford, UK, 1929.

26. Gerard, D. Religious attitudes and values. In Values and Social Change in Britain; Abrams, M., Gerad, D., Timms, N., Eds.; Palgrave Macmillan: London, UK, 1985; pp. 50-92.

27. Shmelev, S.; Shmeleva, I. Sustainability Analysis: An Interdisciplinary Approach; Palgrave Macmillan: London, UK, 2012.

28. Tankha, G. Environmental Attitudes and Awareness: A Psychosocial Perspective; Cambridge Scholars Publishing: Newcastle upon Tyne, UK, 2017.

29. Stern, P.C.; Dietz, T. The value basis of environmental concern. J. Soc. Issues 1994, 50, 65-84. [CrossRef]

30. Singh, M.L.; Karunakaran, T. A sociological study of environmental pollution. J. Educ. Soc. Chang. 1992, 6, 59-64.

31. Nath, B. Environmental Education and Awareness; EOLSS Publications: Oxford, UK, 2016.

32. Sánchez García, J.L.; Díez Sanz, J.M. Climate change, ethics and sustainability: An innovative approach. J. Innov. Knowl. 2018, 3, 70-75. [CrossRef]

33. Schmuck, P.; Schultz, W.P. Psychology of Sustainable Development; Springer: New York, NY, USA, 2012.

34. Barr, S. Factors influencing environmental attitudes and behaviors: A UK case study of household waste management. Environ. Behav. 2007, 39, 435-473. [CrossRef]

35. De Groot, J.I.; Steg, L. Value orientations and environmental beliefs in five countries: Validity of an instrument to measure egoistic, altruistic and biospheric value orientations. J. Cross Cult. Psychol. 2007, 38, 318-332. [CrossRef]

36. Richins, M.L.; Dawson, S. A consumer values orientation for materialism and its measurement: Scale development and validation. J. Consum. Res. 1992, 19, 303-316. [CrossRef]

37. Kasser, T.; Ryan, R.M. Further examining the American dream: Differential correlates of intrinsic and extrinsic goals. Personal. Soc. Psychol. Bull. 1996, 22, 280-287. [CrossRef] 
38. Sarstedt, M.; Hair, J.F.; Ringle, C.M.; Thiele, K.O.; Gudergan, S.P. Estimation issues with PLS and CBSEM: Where the bias lies! J. Bus. Res. 2016, 69, 3998-4010. [CrossRef]

39. Richter, N.F.; Cepeda, G.; Roldán, J.L.; Ringle, C.M. European management research using partial least squares structural equation modeling (PLS-SEM). Eur. Manag. J. 2016, 34, 589-597. [CrossRef]

40. Stan, C. Teoria Educaţiei. Actualitate şi Perspective; Presa Universitară Clujeana: Cluj-Napoca, Romania, 2001.

41. Şchiopu, U. Dicţionar de Psihologie; Babel: Bucharest, Romania, 1997.

42. Chaiklin, H. Attitudes, behavior, and social practice. J. Soc. Soc. Welf. 2011, 38, 31.

43. Cary, J.; Webb, T.; Barr, N. Understanding Landholders' Capacity to Change to Sustainable Practices; CiteULike: Bristol, UK, 2002.

44. Berkes, F. Sacred Ecology; Routledge: Abington, UK, 2012.

45. Berry, T. The Dream of the Earth; Sierra Book Club: San Francisco, CA, USA, 1988.

46. Murray, R. The Cosmic Covenant: Biblical Themes of Justice, Peace and the Integrity of Creation; Gorgias Press LLC: Piscataway, NJ, USA, 2007.

47. Meyfroidt, P. Environmental cognitions, land change, and social-ecological feedbacks: An overview. J. Land Use Sci. 2013, 8, 341-367. [CrossRef]

48. Gardner, G.T. Inspiring Progress: Religions' Contributions to Sustainable Development; Taylor \& Francis: New York, NY, USA, 2006.

49. Tucker, M.E.; Grim, J. Daring to Dream: Religion and the Future of the Earth. Available online: https: / / reflections.yale.edu/article/gods-green-earth/daring-dream-religion-and-future-earth (accessed on 7 August 2018).

50. Lawson, J.; Miller, K.; Wescott, G. Reshaping the Worldview: Case Studies of Faith Groups' Approaches to a New Australian Land Ethic. In The Changing World Religion Map; Springer: Berlin, Germany, 2015; pp. 273-295.

51. Clements, J.M.; Xiao, C.; McCright, A.M. An examination of the "greening of Christianity" thesis among Americans, 1993-2010. J. Sci. Study Relig. 2014, 53, 373-391. [CrossRef]

52. Arbuckle, M.B. The interaction of religion, political ideology, and concern about climate change in the United States. Soc. Nat. Resour. 2017, 30, 177-194. [CrossRef]

53. Kanagy, C.L.; Nelsen, H.M. Religion and environmental concern: Challenging the dominant assumptions. Rev. Relig. Res. 1995, 37, 33-45. [CrossRef]

54. Boyd, H.H. Christianity and the environment in the American public. J. Sci. Study Relig. 1999, 38, 36-44. [CrossRef]

55. Eckberg, D.L.; Blocker, T.J. Christianity, Environmentalism, and the Theoretical Problem of Fundamentalism. J. Sci. Study Relig. 1996, 35, 343-355. [CrossRef]

56. Sherkat, D.E.; Ellison, C.G. Structuring the religion-environment connection: Identifying religious influences on environmental concern and activism. J. Sci. Study Relig. 2007, 46, 71-85. [CrossRef]

57. Kilburn, H.W. Religion and foundations of American public opinion towards global climate change. Environ. Polit. 2014, 23, 473-489. [CrossRef]

58. Konisky, D.M. The greening of Christianity? A study of environmental attitudes over time. Environ. Polit. 2018, 27, 267-291. [CrossRef]

59. Kellert, S.R.; Farnham, T.J.; Farnham, T. The Good in Nature and Humanity: Connecting Science, Religion, and Spirituality with the Natural World; Island Press: Washington, DC, USA, 2002.

60. Walach, H.; Reich, K.H. Reconnecting science and spirituality: Toward overcoming a taboo. Zygon® 2005, 40, 423-442. [CrossRef]

61. Sponsel, L.E. Spiritual Ecology: A Quiet Revolution; ABC-CLIO: Santa Barbara, CA, USA, 2012.

62. Oelschlaeger, M. Caring for Creation: An Ecumenical Approach to the Environmental Crisis; Yale University Press: New Haven, CT, USA, 1996.

63. Tucker, M.E. Touching the Depths of Things: Cultivating Nature in East Asia. In Ecology and the Environment: Perspectives from the Humanities; Harvard Divinity School: Cambridge, MA, USA, 2009; pp. 49-64.

64. Pope Paul VI. Apostolic Letter Octogesima Adveniens. May 14, 1971; AAS, Libreria Editrice Vaticana: Rome, Italy, 1971; Available online: http:/ /w2.vatican.va/content/paul-vi/en/apost_letters/documents/hf_p-vi_ apl_19710514_octogesima-adveniens.html (accessed on 7 August 2018). 
65. Benedict XVI. Address to the Diplomatic Corps Accredited to the Holy See; Libreria Editrice Vaticana: Rome, Italy, 2008; Available online: https:/ /w2.vatican.va/content/francesco/en/speeches/2017/january/documents / papa-francesco_20170109_corpo-diplomatico.html (accessed on 7 August 2018).

66. Vatican. Encyclical Letter Laudato Si of the Holy Father Francis on Care for Our Common Home; 2015. Available online: http:/ / www.environmentandsociety.org/mml/encyclical-letter-laudato-si-holy-fatherfrancis-care-our-common-home (accessed on 7 August 2018).

67. Raven, P.H.I. Our World and Pope Francis' Encyclical, Laudato si'. Q. Rev. Biol. 2016, 91, 247-260. [CrossRef] [PubMed]

68. Wildman, W.; Demm, C. Bibliography in Ecological Ethics and Eco-Theology. Available online: http: / / people.bu.edu/wwildman/WeirdWildWeb/proj_bibs_ecoethics_00.htm (accessed on 7 August 2018).

69. Hitzhusen, G.E. Understanding the role of spirituality and theology in outdoor environmental education: A mixed-method characterization of 12 Christian and Jewish outdoor programs. Res. Outdoor Educ. 2005, 7, $39-56$.

70. Gookin, J. Spirituality: The softer side of education. In NOLS Environmental Education Notebook; 2002; pp. 7-8. Available online: https:/ /www.amazon.com/NOLS-Environmental-Education-Notebook-Gookin/dp/ B00T2DMO4G (accessed on 7 August 2018).

71. Hungerford, H.R.; Volk, T.L. Changing learner behavior through environmental education. J. Environ. Educ. 1990, 21, 8-21. [CrossRef]

72. Farrior, M.; Lowry, S. Building Partnerships with the Faith Community: A Resource Guide for Environmental Groups; The Biodiversity Project: Madison, WI, USA, 2001.

73. McKibben, B. Simpler Living, Compassionate Life: A Christian Perspectiv; Church Publishing, Inc.: New York, NY, USA, 2009.

74. Bakken, P.W.; Engel, J.G.; Engel, J.R. Ecology, Justice, and Christian Faith: A Critical Guide to the Literature; Greenwood Publishing Group: Westfield, CT, USA, 1995.

75. Kempton, W.; Boster, J.S.; Hartley, J.A. Environmental Values in American Culture; MIT Press: Cambridge, MA, USA, 1996.

76. Pickard, R. Management of Historic Centres; Taylor \& Francis: London, UK, 2013.

77. Santos Solla, X.M. El Camino de Santiago: Turistas y peregrinos hacia Compostela. Cuadernos de Turismo 2006, 18, 135-150.

78. UNWTO. UNWTO World Tourism Barometer; United Nations World Tourism Organization: Madrid, Spain, 2017.

79. Peeters, P.; Dubois, G. Tourism travel under climate change mitigation constraints. J. Transp. Geogr. 2010, 18, 447-457. [CrossRef]

80. Gössling, S. Global environmental consequences of tourism. Glob. Environ. Chang. 2002, 12, $283-302$. [CrossRef]

81. Cohen, E. Authenticity, equity and sustainability in tourism. J. Sustain. Tour. 2002, 10, 267-276. [CrossRef]

82. Parga-Dans, E. Socio-economic impacts of the Camino to Finisterre. In Heritage, Pilgrimage and the Camino to Finisterre: Walking to the End of the World; Sánchez-Carretero, C., Ed.; Springer: Cham, Switzerland, 2015; pp. 121-134.

83. Collins-Kreiner, N. Researching pilgrimage: Continuity and transformations. Ann. Tour. Res. 2010, 37, 440-456. [CrossRef]

84. Hall, C.M. Tourism and Social Marketing; Routledge: London, UK, 2014.

85. Thrane, C. Research Note: The determinants of tourists' length of stay: Some further modelling issues. Tour. Econ. 2015, 21, 1087-1093. [CrossRef]

86. Divisekera, S. Economics of tourist's consumption behaviour: Some evidence from Australia. Tour. Manag. 2010, 31, 629-636. [CrossRef]

87. Santos, G.E.D.O.; Ramos, V.; Rey-Maquieira, J. Length of stay at multiple destinations of tourism trips in Brazil. J. Travel Res. 2015, 54, 788-800. [CrossRef]

88. Brida, J.G.; Meleddu, M.; Pulina, M. Factors influencing length of stay of cultural tourists. Tour. Econ. 2013, 19, 1273-1292. [CrossRef]

89. Barros, C.P.; Butler, R.; Correia, A. The length of stay of golf tourism: A survival analysis. Tour. Manag. 2010, 31, 13-21. [CrossRef] 
90. Murray, M.; Graham, B. Exploring the dialectics of route-based tourism: The Camino de Santiago. Tour. Manag. 1997, 18, 513-524. [CrossRef]

91. Pan, S.-Y.; Gao, M.; Kim, H.; Shah, K.J.; Pei, S.-L.; Chiang, P.-C. Advances and challenges in sustainable tourism toward a green economy. Sci. Total Environ. 2018, 635, 452-469. [CrossRef] [PubMed]

92. Higgins-Zogib, L.; Dudley, N.; Aziz, T.; Malla, S. The High Ground: Sacred Natural Sites, Bio-Cultural Diversity and Climate Change in the Eastern Himalayas; WWF: Grand, Switzerland, 2012.

93. Wiscombe, C.A. Sustainability, ethics and social responsibility: A developed economies perspective. In Rural Tourism and Enterprise: Management, Marketing and Sustainability; Oriade, A., Robinson, P., Eds.; CABI: Wallingford, UK, 2017; pp. 34-52.

94. Chu, H.; Lai, C.-C. Abatement R\&D, market imperfections, and environmental policy in an endogenous growth model. J. Econ. Dyn. Control 2014, 41, 20-37.

95. Itaya, J.-I. Can environmental taxation stimulate growth? The role of indeterminacy in endogenous growth models with environmental externalities. J. Econ. Dyn. Control 2008, 32, 1156-1180. [CrossRef]

96. Olivier, B.; David, T.; Pascal, P. Leading by example: A model of organizational citizenship behavior for the environment. Bus. Strategy Environ. 2015, 24, 532-550.

97. Kaya, N.Ç.; Turan, F. Sekizinci sınıf öğrencilerinin çevreye ilişkin bilgi ve duyarlılıkları: Ankara'da resmi ve özel ilköğretim okulları örneğinde bir çalışma. Eurasian J. Educ. Res. 2005, 21, 103-112.

98. Siero, S.; Boon, M.; Kok, G.; Siero, F. Modification of driving behavior in a large transport organization: A field experiment. J. Appl. Psychol. 1989, 74, 417-423. [CrossRef]

99. Lee, Y.-J.; De Young, R.; Marans, R.W. Factors influencing individual recycling behavior in office settings: A study of office workers in Taiwan. Environ. Behav. 1995, 27, 380-403. [CrossRef]

100. Lo Siu, H.; Peters Gjalt-Jorn, Y.; Kok, G. Energy-related behaviors in office buildings: A qualitative study on individual and organisational determinants. Appl. Psychol. 2012, 61, $227-249$.

101. Bhanot, N.; Rao, P.V.; Deshmukh, S.G. An integrated approach for analysing the enablers and barriers of sustainable manufacturing. J. Clean. Prod. 2017, 142, 4412-4439. [CrossRef]

102. Brundage, M.P.; Bernstein, W.Z.; Hoffenson, S.; Chang, Q.; Nishi, H.; Kliks, T.; Morris, K.C. Analyzing environmental sustainability methods for use earlier in the product lifecycle. J. Clean. Prod. 2018, 187, 877-892. [CrossRef]

103. Shieh, J.-Y.; Chen, J.-H.; Chang, S.-H.; Lai, C.-C. Environmental consciousness, economic growth, and macroeconomic instability. Int. Rev. Econ. Finan. 2014, 34, 151-160. [CrossRef]

104. Tsai, C.-C.; Stritch, J.M.; Christensen, R.K. Eco-helping and eco-civic engagement in the public workplace. Public Perform. Manag. Rev. 2016, 40, 336-360. [CrossRef]

105. Gupta, V. Sustainable tourism: Learning from Indian religious traditions. Int. J. Contemp. Hosp. Manag. 1999, 11,91-95. [CrossRef]

106. Mieczkowski, Z. Environmental Issues of Tourism and Recreation; University Press of America: Lanham, MD, USA, 1995.

107. Budeanu, A. Impacts and responsibilities for sustainable tourism: A tour operator's perspective. J. Clean. Prod. 2005, 13, 89-97. [CrossRef]

108. Ones Deniz, S.; Dilchert, S. Environmental sustainability at work: A call to action. Ind. Organ. Psychol. 2012, 5, 444-466. [CrossRef]

109. Hitzhusen, G.E. Religion and environmental education: Building on common ground. Can. J. Environ. Educ. 2006, 11, 9-25.

110. Chen, C.-L.; Tsai, C.-H. Marine environmental awareness among university students in Taiwan: A potential signal for sustainability of the oceans. Environ. Educ. Res. 2016, 22, 958-977. [CrossRef]

111. Manea, A.D. Influences of religious education on the formation moral consciousness of students. Procedia Soc. Behav. Sci. 2014, 149, 518-523. [CrossRef]

112. Miller, L.; Zeigler-Hill, V.; Mellen, J.; Koeppel, J.; Greer, T.; Kuczaj, S. Dolphin shows and interaction programs: Benefits for conservation education? Zoo Biol. 2013, 32, 45-53. [CrossRef] [PubMed]

113. Farmer, J.; Knapp, D.; Benton, G.M. An elementary school environmental education field trip: Long-term effects on ecological and environmental knowledge and attitude development. J. Environ. Educ. 2007, 38, 33-42. [CrossRef]

114. Forleo, M.B.; Gagliardi, N.; Romagnoli, L. Determinants of willingness to pay for an urban green area: A contingent valuation survey of college students. Int. J. Manag. Knowl. Learn. 2015, 4, 7-25. 
115. Krasny, M.E.; Tidball, K.G. Applying a resilience systems framework to urban environmental education. Environ. Educ. Res. 2009, 15, 465-482. [CrossRef]

116. Ajzen, I.; Fishbein, M. Attitudes and the attitude-behavior relation: Reasoned and automatic processes. Eur. Rev. Soc. Psychol. 2000, 11, 1-33. [CrossRef]

117. Eagly, A.H.; Chaiken, S. The Psychology of Attitudes; Harcourt Brace Jovanovich College Publishers: San Diego, CA, USA, 1993.

118. Olson, J.M.; Zanna, M.P. Attitudes and attitude change. Ann. Rev. Psychol. 1993, 44, 117-154. [CrossRef]

119. Robina Ramírez, R.; Pulido Fernández, M. Religious Experiences of Travellers Visiting the Royal Monastery of Santa María de Guadalupe (Spain). Sustainability 2018, 10, 1890. [CrossRef]

120. Gottlieb, R.S. This Sacred Earth: Religion, Nature, Environment; Routledge: London, UK, 2003.

121. Hair, J.F.; Black, W.C.; Babin, B.J.; Anderson, R.E.; Tatham, R.L. Multivariate Data Analysis; Prentice Hall: New York, NY, USA, 1998; Volume 5.

122. Page, S.; Ateljevic, J. Tourism and Entrepreneurship: International Perspectives; Pergamon: Oxford, UK, 2011.

123. Bollen, K.A. Structural Equations with Latent Variables; Wiley: New York, NY, USA, 1989.

124. Jöreskog, K.G. Testing structural equation models. Sage Focus Ed. 1993, 154, 294.

125. Lohmöller, J.-B. Latent Variable Path Modeling with Partial Least Squares; Springer: New York, NY, USA, 2013.

126. Wold, H. Partial least squares. In Encyclopedia of Statistical Sciences; Kotz, S., Johnson, N.L., Eds.; Wiley: New York, NY, USA, 1985; pp. 581-591.

127. Dijkstra, T.K.; Henseler, J. Consistent Partial Least Squares Path Modeling. MIS Q. 2015, 39, $297-316$. [CrossRef]

128. Chin, W.W.; Newsted, P.R. Structural equation modeling analysis with small samples using partial least squares. Stat. Strateg. Small Sample Res. 1999, 1, 307-341.

129. Diamantopoulos, A.; Riefler, P. Using formative measures in international marketing models: A cautionary tale using consumer animosity as an example. In Measurement and Research Methods in International Marketing; Emerald Group Publishing Limited: Bingley, UK, 2011; pp. 11-30.

130. Astrachan, C.B.; Patel, V.K.; Wanzenried, G. A comparative study of CB-SEM and PLS-SEM for theory development in family firm research. J. Fam. Bus. Strategy 2014, 5, 116-128. [CrossRef]

131. Hair, J.F., Jr.; Hult, G.T.M.; Ringle, C.; Sarstedt, M. A Primer on Partial Least Squares Structural Equation Modeling (PLS-SEM); Sage Publications: New York, NY, USA, 2016.

132. Henseler, J.; Ringle, C.M.; Sinkovics, R.R. The use of partial least squares path modeling in international marketing. In New Challenges to International Marketing; Zou, S., Ed.; Emerald Group Publishing Limited: Bingley, UK, 2009; Volume 20, pp. 277-319.

133. Anderson, J.C.; Gerbing, D.W. Structural equation modeling in practice: A review and recommended two-step approach. Psychol. Bull. 1988, 103, 411-423. [CrossRef]

134. Chin, W.W. The partial least squares approach to structural equation modeling. In Modern Methods for Business Research; Marcoulides, G.A., Ed.; Psychology Press: London, UK, 2013; pp. 295-336.

135. Falk, R.F.; Miller, N.B. A Primer for Soft Modeling; University of Akron Press: Akron, OH, USA, 1992.

(C) 2018 by the authors. Licensee MDPI, Basel, Switzerland. This article is an open access article distributed under the terms and conditions of the Creative Commons Attribution (CC BY) license (http://creativecommons.org/licenses/by/4.0/). 